\title{
Penggunaan Kontrasepsi Hormonal Berhubungan dengan Penurunan Kualitas Fisik dan Mental Sosial Akseptor
}

\author{
Use of Hormonal Contraception is Associated with a Decreased Quality of Physical \\ and Mental Acceptance of Social
}

\author{
Martini Martini ${ }^{1, \otimes}$, Martini Fairus $^{1}$ \\ ${ }^{1}$ Jurusan Kebidanan, Politeknik Kesehatan Tanjung Karang, Indonesia \\ ${ }^{凶}$ Corresponding author: martini.mubarok@gmail.com
}

Kata kunci:
Kontrasepsi hormonal,
kualitas hidup,
akseptor

Keyword:

Hormonal

contraception, quality

of life,

acceptor

\begin{abstract}
Abstrak
Latar belakang: Penggunaan kontrasepsi yang mengandung hormon sintetik untuk pencegehan kehamilan bukanlah tanpa risiko. Penggunaan terus menerus selama lebih dari 5 tahun meningkatkan risiko 40\%, 10 tahun $80 \%$ dan 20 tahun $160 \%$ untuk mendapatkan kanker. Tujuan: Penelitian ini bertujuan untuk mengetahui hubungan penggunaan kontrasepsi hormonal dengan kualitas hidup fisik dan mental sosial. Metode: Rancangan penelitian ini adalah cross sectional yang dilakukan pada bulan September 2017. Populasi penelitian adalah pengguna kontrasepsi hormonal di Poskeskel Kecamatan Metro Selatan kota Metro pada tahun 2017 dengan jumlah sampel 138 orang. Data yang dkumpulkan menggunakan alat kuesioner untuk memperoleh data kontrasepsi hormonal akseptor dan kualitas hidup fisik dan mental sosial dan analisis bivariat menggunakan uji chi square. Hasil: Hasil penelitian menunjukkan terdapat hubungan yang signifikan antara kontrasepsi hormonal dengan kesehatan fisik (p 0,010) dan hubungan yang signifikan antara Kontrasepsi hormonal dengan kesehatan mental sosial (p 0,014). Simpulan: Penggunaan kontrasepsi hormonal berhubungan penurunan kesehatan fisik dan kesehatan mental sosial. Akseptor yang menggunakan kontrasepsi hormonal memiliki skor kesehtan fisik dan mental yang lebih rendah dibandingkan pengguna kotrasepsi non hormonal.
\end{abstract}

\begin{abstract}
Background: The use of contraceptives that contain synthetic hormones for pregnancy prevention is not without risk. Continuous use for more than 5 years increases the risk of 40\%, 10 years $80 \%$ and 20 years $160 \%$ to get cancer. Purpose: This study aims to determine the relationship of hormonal contraceptive use with physical and mental quality of life. Methods: The study design was cross sectional conducted in September 2017. The study population was hormonal contraceptive users in Metro Selatan Subdistrict, Metro City in 2017 with a total sample of 138 people. Data collected using a questionnaire to obtain hormonal contraceptive acceptor data and quality of life physically and mentally social and bivariate analysis using chi square test. Results: The results showed a significant relationship between hormonal contraception and physical health (p 0.010) and a significant relationship between hormonal contraception and social mental health ( $p$ 0.014). Conclusion: The use of hormonal contraception is related to decreased physical health and social mental health. Acceptors using hormonal contraception have lower physical and mental health scores than non-hormonal contraceptive users.
\end{abstract}

Copyright $@ 2017$ Jurnal Kesehatan Metro Sai Wawai. All rights reserved. 


\section{Pendahuluan}

Program Keluarga Berencana adalah program pemerintah yang bertujuan untuk mengendalikan angka kelahiran. Tujuan Keluarga Berencana menurut BKKBN tahun 2012 adalah meningkatkan derajat kesehatan dan kesejahteraan ibu, anak serta keluarga dan bangsa pada umumnya. Program Keluarga Berencana ini tidak terlepas dari penggunaan Kontrasepsi hormonal. Kontrasepsi hormonal merupakan kontrasepsi yang mengandung hormon sintetik terdiri dari kombinasi hormon estrogen dan progesteron atau hanya berisi hormon progesteron saja. Estrogen bekerja dengan jalan mempengaruhi ovulasi, menghambat perjalanan sel telur atau implantasi sedangkan progesteron bekerja dengan menyebabkan lendir serviks menjadi lebih kental (Hartanto, 2010).

Selain keefektifannya dalam mencegah kehamilan, kontrasepsi hormonal ternyata juga mempunyai beberapa efek samping yang dapat mempengaruhi kesehatan. Menurut Dr Hilda Hutcherson, seorang Profesor Bidang Kebidanan dan Kandungan Columbia University New York, bahwa penggunaan kontrasepsi pil dapat menyebabkan beberapa efek samping yaitu pusing, mual, nyeri payudara, mood naik turun dan diduga penggunaan pil dapat menurunkan kadar testosteron dalam tubuh sehingga dapat menurunkan libido pada penggunanya. Selain itu efek samping terjadinya perdarahan diluar masa haid sering terjadi pada akseptor mini pil, suntik dan implan. Pada tahun 2007 Gezginc et al melakukan sebuah studi pada akseptor kontrasepsi implan dan menemukan adanya kasus amenorhoe, perdarahan jarang, perdarahan berkepanjangan, nyeri payudara, berjerawat, sakit kepala dan pusing, gangguan mood, nyeri panggul dan penurunan libido (Gezginc, 2007). Pengguna kontrasepsi oral memiliki skor Female Sexual Function Index (FSFI) yang lebih rendah dibanding dengan yang tidak menggunakan Kontrasepsi hormonal. Penelitian lain dilakukan oleh Hanna menyimpulkan bahwa terdapat peningkatan depresi dan rendahnya hasrat seksual pada akseptor kontrasepsi pil (Ventegody, 2003).

Kontrasepsi hormonal juga dikaitkan dengan risiko kenaikan berat badan, penyakit cardiovasculer, dislipidemia, infark miocar, tromboemboli vena dan stroke. Hasil penelitian yang dilakukan oleh Andrea, et al (2012), menyimpulkan bahwa terdapat peningkatan yang signifikan pada nilai glucosa plasma, HOMA- $\beta$, high density lipoprotein colesterol (HDLC), trigliserida, asam lemak bebas dan kolesterol total pada akseptor kontrasepsi suntik dibanding dengan yang tidak menggunakan kontrasepsi suntik (Andrea, 2012). George et al (2014) menemukan bahwa penggunaan Kontrasepsi suntik dikaitkan dengan peningkatan secara signifikan pada Indeks Massa Tubuh (BMI), tekanan darah diastolik, Colesterol total (TC), indeks Castelli I dan II dan Low- density lipoprotein colesterol (LDLC) yang berisiko pada potensial terjadinya penyakit cardio vasculer (George, et al, 2014).

Data SDKI 2012 menunjukkan peningkatan prevalensi penggunaan kontrasepsi atau Contraceptive Prevalence Rate (CPR) di Indonesia sejak 1991-2012 sementara angka fertilitas atau Total Fertility Rate (TFR) cenderung menurun. Tren dini menggambarkan bahwa meningkatnya cakupan usia15-49 tahun yang melakukan KB sejalan dengan menurunnya angka fertilitas nasional (Kemenkes, 2015).

Pada tahun 2015, persentase KB baru terhadap pasangan usia subur di Indonesia adalah sebesar 13,46\%, lebih rendah dibandingkan capaian 2014 yang sebesar 16,51\%. Peserta KB baru dan KB aktif menunjukkan pola yang sama dalam pemilihan kontrasepsi. Pilihan kontrasepsi suntik menjadi primadona dalam penggunaan kontrasepsi. Berdasarkan data (BKKBN, 2015). Kontrasepsi suntik menempati urutan pertama yaitu sebesar $(49,93 \%)$ di ikuti kontrasepsi pil pada urutan kedua $(26,36 \%)$ dan urutan ketiga adalah kontrasepsi implant $(9,63 \%)$ sedangkan kontrasepsi non hormonal IUD, kondom, MOW dan MOP hanya (14,8\%) dari seluruh pemakaian alat kontrasepsi (Kemenkes, 2015).

Kontrasepsi suntik merupakan jenis kontrasepsi yang paling banyak digunakan di indonesia. 
Menurut hasil Survei Sosial Ekonomi Nasional (Susenas) tahun 2015 dari jumlah Pasangan Usia Subur (PUS) sebesar 48.609 juta pasangan, jumlah PUS yang menggunakan kontrasepsi modern mencapai 58,99\% dari total PUS. Kontrasepsi modern meliputi Kontrasepsi suntik, Pil, Implan, IUD dan kontrasepsi pria (MOP dan kondom) yang hanya mencapai 1,27\%. Jenis Kontrasepsi suntik paling diminati para ibu karena sangat efektif dalam mencegah terjadinya kehamilan. Berdasarkan data BKKBN Provinsi Lampung pada tahun 2015 persentase wanita berstatus kawin yang menggunakan alat kontrasepsi atau KB aktif adalah sebesar 21,8\%. Adapun data BPS Metro Selatan menyebutkan jumlah pengguna alat kontrasepsi jangka panjang (MKPJ) terdiri dari IUD 3.042 orang, MOP 79 orang, dan MOW 662 orang. Sedangkan alat kontrasepsi non MKPJ terdiri atas suntik 7.784orang danpil 5.072 orang (BKKBN, 2015).

Kandungan hormon sintetik yang ada didalam kontrasepsi baik estrogen maupun progesteron tidak baik untuk kesehatan tubuh karrena berisiko meningkatkan tekananan darah dan jantung. Penggunaan terus menerus selama lebih dari 5 tahun mmeningkatkan risiko 40\%, 10 tahun $80 \%$ dan 20 tahun $160 \%$ untuk mendapatkan kanker. Progestin tidak direkomendasikan bagi wanita yang berumur > 35 tahun karena dapat meningkatkan risiko bagi kesehatan wanita tersebut . Menuru Varney (2010), efek samping dari kandungan hormon progesteron yang berlebihan pada sistem kardiovaskuler dapat menyebabkan perubahan tekanan darah. Risiko terjadinya tekanan darah tinggi akan meningkat dengan bertambahnya umur, lama pemakaian kontrasepsi dan penggunaan jangka panjang (Gezginc, Karatayli \& Colakoglu, 2007).

Faktor-faktor fisiologis utama yang dapat mempengaruhi tekanan darah. Usia, emosi, tekanan darah biasanya tingggi pada orang-orang yang gemuk, Frekuensi dan kekuatan kontraksi jantung, resistensi perifer, kehilangan darah, Hormon. Beberapa hormon memiliki efek terhadap tekanan darah. Contohnya, pada saat stress, medula kelenjar adrenal akan menyekresikan norepinefrin dan epinefrin, yang keduanya akan menyebabkan vasokonstriksi sehingga meningkatkan tekanan darah. Selain dari vasokonstriksi, epinefrin juga berfungsi meningkatkan heart rate dan gaya kontraksi.

Kualitas hidup akhir-akhir ini makin banyak didengungkan. WHO mengungkapkan bahwa kualitas hidup dipengaruhi oleh kesehatan fisik, mental, psikologi, dan seksualitas. Faktor lain yang memengaruhi kualitas hidup, di antaranya usia, pendidikan, status sosial ekonomi. Kesehatan fisik saling berhubungan dan tidak dapat dipisahkan dari kesehatan mental. Begitu pula dengan seksualitasnya. Masing-masing saling memengaruhi satu sama lain. Masalah seksual termasuk gangguan keinginan, gairah seksual, lubrikasi, orgasme, dan rasa sakit. Masalah tersebut tanpa melihat faktor usia, dapat memberikan dampak negatif terhadap kualitas hidup dan kesehatan emosi. Efek kontrasepsi suntik terhadap kualitas hidup akseptor adalah penyakit yang umum dimana dua dari lima wanita memiliki setidaknya satu jenis efek kontrasepsi suntik terhadap kualitas hidup akseptor, dan keluhan yang paling banyak terjadi adalah rendahnya gairah seksual/libido.

Hasil penelitian yang dilakukan Endah di Kecamatan Pakem tahun 2012 tentang kualitas hidup akseptor kontrasepsi hormonal dan non hormonal, menunjukkan adanya perbedaan kualitas hidup aksepstor pengguna kontrasepsi non homonal $(79,35)$ lebih tinggi dibandingkan akseptor kontrasepsi homonal $(77,52)$. Belum adanya penelitian-penelitian yang mengkaji secara mendalam efek kontrasepsi hormonal terhadap kualitas hidup akseptor di Metro Selatan, menjadi alasan bagi penulis untuk melakukan penelitian. Sehubungan dengan hal tersebut, peneliti ingin mengetahui hubungan penggunaan kontrasepsi hormonal dengan kualitas hidup akseptor, sebagai penelitian dasar yang diharapkan dapat digunakan dalam penelitan selanjutnya. Penelitian ini bertujuan untuk mengetahui hubungan penggunaan kontrasepsi hormonal dengan kualitas hidup fisik dan mental sosial di Kecamatan Metro Selatan kota Metro pada tahun 2017. 


\section{Metode}

Pada penelitian ini digunakan metode penelitian observasional analitik dengan pendekatan crosssectional yang dilakukan pada bulan September 2017. Rancangan penelitian digunakan untuk mengetahui hubungan penggunaan kontrasepsi hormonal dengan kualitas hidup fisik dan mental sosial. Populasi penelitian adalah akseptor kontrasepsi hormonal di wilayah Metro Selatan, tahun 2017 dengan jumlah sampel minimal 138 yang dihitung dengan rumus uji sampel beda proporsi. Teknik pengambilan sampel menggunakan simple random sampling.

Jenis data yang digunakan dalam penelitian ini adalah data primer dari akseptor kontrasepsi hormonal di wilayah Metro Selatan tahun 2017 saat penelitian. Pengumpulan data penelitian ini dikumpulkan alat kuesioner setelah mengisi informed consent. Dalam pelaksanaan pengumpulan data dalam dibantu oleh enumerator berjumlah 3 (tiga) orang sudah dilatih terlebih dahulu dalam menjelaskan tujuan penelitian, meminta persetujuan responden, menjelaskan cara pengisian kuesioner dan pendampingan dalam pengisian kuesioner untuk meminimalkan bias hasil pengumpulan data. Analisis data menggunakan analisis univariat dan bivariat. Analisis bivariat dilakukan dengan uji chisquare.

\section{Hasil}

\section{Gambaran variabel penelitian}

Tabel tabel 1 memperlihatkan kontrasepsi hormonal merupakan pilihan yang banyak diminati (79,71\%) dan kontrasepsi suntik merupakan pilihan utama responden. Kontrasepsi suntik menempati urutan pertama pilihan responden $(49,26 \%)$ diikuti kontrsepsi implant dan pil. Kualitas hidup responden yang diukur dengan indikator kesehatan fisik sebagian besar responden adalah baik $(51,45 \%)$ dan sebagian besar responden dengan kesehatan mental sosial kurang baik $(57,97 \%)$.

Tabel 1.

Distribusi variabel penelitian menurut pengguna kontrasepsi dan kualitas hidup responden

\begin{tabular}{|c|c|c|c|}
\hline Variabel & Kategorik & $\begin{array}{c}\text { Jumlah } \\
n=138\end{array}$ & $\begin{array}{c}\text { Persentase } \\
(\%)\end{array}$ \\
\hline \multirow[t]{2}{*}{ Penggunaan kontrasepsi } & Hormonal & 110 & 51,45 \\
\hline & Non hormonal & 28 & 48,55 \\
\hline \multirow[t]{2}{*}{ Kesehatan fisik } & Baik & 71 & 51,45 \\
\hline & Kurang & 67 & 48,55 \\
\hline \multirow[t]{2}{*}{ Kesehatan mental dan sosial } & Baik & 58 & 42,03 \\
\hline & Kurang & 80 & 57,97 \\
\hline
\end{tabular}

\section{Hasil analisis bivariat}

Analisis bivariat dilakukan untuk mengetahui hubungan antara variabel Kontrasepsi hormonal dengan variabel kualitas hidup dengan indikator yang diukur kesehatan fisik dan kesehatan mental dan sosial. Tabel 2 memperlihatkan bahwa dari 110 responden yang menggunakan kontrasepsi hormonal 54,5\% dengan skor kesehatan fisik yang kurang baik. Sedangkan, 28 responden akseptor kontrasepsi non hormonal, ada sebanyak $75 \%$ dengan kesehatan fisik yang baik. Hasil uji chi square diperoleh ada hubungan yang bermakna antara penggunaan kontrasepsi hormonal dengan kesehatan fisik (nilai $\mathrm{p}$ 0,010). Pengguna kontrasepsi hormonal berisiko 3,15 kali untuk mengalami kesehatan fisik kurang dibandingkan yang tidak menggunakan kontrasepsi hormonal.

Tabel 3 menunjukkan kesehatan mental sosial dengan penggunaan kontrasepsi hormonal di peroleh hasil bahwa dari 110 responden yang menggunakan kontrasepsi suntik berjumlah 63,6\% dengan 
skor kesehatan mental yang kurang baik. Sedangkan, 28 responden akseptor kontrasepsi non hormonal berjumlah 64,3\% dengan kesehatan mental sosial yang baik. Hasil uji chi square diperoleh ada hubungan yang bermakna antara penggunaan kontrasepsi hormonal dengan kesehatan mental sosial pengguna kontrasepsi hormonal (nilai p 0,014). Pengguna kontrasepsi hormonal berisiko 3,15 kali untuk mengalami depresi dibandingkan yang tidak menggunakan kontrasepsi hormonal.

Tabel 2.

Hubungan Kontrasepsi Hormonal dengan Kesehatan Fisik pada Responden

\begin{tabular}{|c|c|c|c|c|c|c|c|c|}
\hline \multirow{3}{*}{ Jenis Kontrasepsi } & \multicolumn{4}{|c|}{ Kesehatan Fisik } & \multirow{2}{*}{\multicolumn{2}{|c|}{ Total }} & \multirow{3}{*}{$\begin{array}{c}\text { OR } \\
95 \% \mathrm{CI}\end{array}$} & \multirow{3}{*}{$\begin{array}{c}P \\
\text { value }\end{array}$} \\
\hline & \multicolumn{2}{|c|}{ Kurang } & \multicolumn{2}{|c|}{ Baik } & & & & \\
\hline & $\mathbf{n}$ & $\%$ & $\mathbf{n}$ & $\%$ & $\mathbf{n}$ & $\%$ & & \\
\hline Hormonal & 60 & 54,5 & 50 & 45,5 & 110 & 100 & \multirow{3}{*}{$\begin{array}{c}3,600 \\
(1.4-9.2)\end{array}$} & \multirow{3}{*}{0,010} \\
\hline Non Hormonal & 7 & 25 & 21 & 75 & 28 & 100 & & \\
\hline Jumlah & 67 & 48,6 & 71 & 51,4 & 138 & 100 & & \\
\hline
\end{tabular}

Tabel 3.

Hubungan Kontrasepsi Hormonal dengan Kesehatan Mental Sosial pada Responden

\begin{tabular}{|c|c|c|c|c|c|c|c|c|}
\hline \multirow{3}{*}{ Jenis Kontrasepsi } & \multicolumn{4}{|c|}{ Kesehatan Mental sosial } & \multirow{2}{*}{\multicolumn{2}{|c|}{ Total }} & \multirow{3}{*}{$\begin{array}{c}\text { OR } \\
95 \% \mathrm{CI}\end{array}$} & \multirow{3}{*}{$\begin{array}{c}P \\
\text { value }\end{array}$} \\
\hline & \multicolumn{2}{|c|}{ Kurang } & \multicolumn{2}{|c|}{ Baik } & & & & \\
\hline & $\mathbf{n}$ & $\%$ & $\mathbf{n}$ & $\%$ & $\mathbf{n}$ & $\%$ & & \\
\hline Hormonal & 70 & 63,6 & 40 & 36,4 & 110 & 100 & 3,150 & \\
\hline Non hormonal & 10 & 35,7 & 18 & 64,3 & 28 & 100 & $(1.3-7,5)$ & 0,014 \\
\hline Total & 80 & 58 & 59 & 42 & 138 & 100 & & \\
\hline
\end{tabular}

\section{Pembahasan}

\section{Gambaran penggunaan kontrasepsi hormonal dan non hormon}

Hasil analisis univariat didapatkan 110 responden $(79,71 \%)$ akseptor menggunakan kontrasepsi metode kontrasepsi suntik, dan sebanyak 28 orang (20,29\%) akseptor menggunakan kontrasepsi non hormonal. Hal ini sesuai dengan SDKI. Pada tahun 2015 yang menggambarkan bahwa persentase KB baru terhadap pasangan usia subur di Indonesia adalah sebesar 13,46\%, lebih rendah dibandingkan capaian 2014 yang sebesar 16,51\%. Peserta KB baru dan KB aktif menunjukkan pola yang sama dalam pemilihan kontrasepsi. Pilihan kontrasepsi suntik menjadi primadona dalam penggunaan kontrasepsi. Berdasarkan data (BKKBN, 2015) kontrasepsi suntik menempati urutan pertama sebesar 49,93\% diikuti kontrasepsi pil pada urutan kedua $(26,36 \%)$ dan urutan ketiga adalah kontrasepsi implant 9,63\%, sedangkan kontrasepsi non hormonal IUD, kondom, MOW dan MOP hanya $(14,8 \%)$ dari seluruh pemakaian alat kontrasepsi.

\section{Hubungan antara kontrasepsi kontrasepsi hormonal terhadap kesehatan fisik}

Hasil penelitian menunjukkan bahwa skor kesehatan fisik pada akseptor hormonal lebih rendah dibandingkan wanita dengan kontrasepsi non hormonal. Sama dengan skor total kesehatan fisik pada akseptor hormonal lebih rendah dibandingkan wanita dengan kontrasepsi non hormonal. Terdapat dari 110 responden yang menggunakan kontrasepsi hormonal ada 54,5\% dengan skor kesehatan fisik yang kurang baik. Sedangkan, 28 responden akseptor kontrasepsi non hormonal terdadapt $75 \%$ dengan kesehatan fisik yang baik. Ada hubungan yang bermakna antara penggunaan kontrasepsi hormonal dengan kesehatan fisik (nilai p 0,010). Pengguna kontrasepsi hormonal berisiko 3,15 kali untuk mengalami kesehatan fisik kurang dibandingkan yang tidak menggunakan kontrasepsi hormonal.

Hasil penelitian ini sesuai dengan teori yang menyebutkan bahwa ada beberapa hormon 
memiliki efek terhadap tekanan darah. Contohnya, pada saat stress, medula kelenjar adrenal akan menyekresikan norepinefrin dan epinefrin, yang keduanya akan menyebabkan vasokonstriksi sehingga meningkatkan tekanan darah. Tekanan darah yang meningkat menyebabkan peningkatan risiko gangguan kesehatan pada akseptor pengguna kontrasepsi hormonal (Eviana.S,2011).

Kondisi ini dapat berkaitan dengan kadar hormon didalam darah bahwa setelah menggunakan kontrasepsi hormonal yang mengandung progesteron, taraf hormon estrogen alami dalam tubuh wanita menurun drastis. Akibatnya dapat dengan mudah terjadi ketidakstabilan tekanan darah, keabnormalan metabolisme lemak darah dan keabnormalan gula darah, sehingga risiko terkena penyakit metabolisme meningkat.

\section{Hubungan antara kontrasepsi hormonal terhadap kesehatan mental sosial}

Penelitian tentang kesehatan mental sosial dengan penggunaan kontrasepsi hormonal di Poskeskel Kecamatan Metro Selatan diperoleh hasil bahwa dari 110 responden yang menggunakan kontrasepsi hormonal berjumlah 63,6\% dengan skor kesehatan mental yang kurang baik. Sedangkan, 28 responden akseptor kontrasepsi non hormonal terdapat sebanyak 64,3\% dengan kesehatan mental sosial yang baik. Ada hubungan yang bermakna antara penggunaan kontrasepsi hormonal dengan kesehatan mental sosial pengguna kontrasepsi hormonal (nilai p 0,014). Pengguna kontrasepsi hormonal berisiko 3,15 kali untuk mengalami depresi dibandingkan yang tidak menggunakan kontrasepsi hormonal.

Terdapat pengaruh lamanya penggunaan alat kontrasepsi hormonal terhadap tingkat depresi diakibatkan berkurangnya tingkat serotonin dalam otak secara terus menerus. Salah satu fungsi serotonin adalah pengatur mood atau perasaan seseorang. Penelitian kontrasepsi hormonal terhadap kejadian depresi sudah banyak dilakukan. Salah satu etiologi depresi yang paling banyak adalah depresi yang disebab kan oleh gangguan regulasi serotonin, dopamin, dan norepinefrin. Gangguan dari regulasi neurotransmitter tersebut disebabkan oleh terganggunya produksi alami hormon progesteron dan estrogen dalam tubuh. Saat ini serotonin dan norepinefrin merupakan neurotrasmitter utama dalam mengakibatkan gangguan depresi. Dalam kasus depresi, serotonin bertanggungjawab untuk kontrol regulasi afek, agresi tidur, dan nafsu makan. Pada beberapa penelitian ditemukan jumlah serotonin yang berkurang di celah sinap dikatakan bertanggung jawab dalam terjadinya depresi (Natalia, 2014). Serotonin di otak disekresikan oleh reph nuclei di batang otak. Serotonin disintesis oleh prekusornya yaitu triptofan dibantu enzim triptofan hidroksilase dan asam amino aromatik dekarboksilase, serotonin yang terbentuk kemudian disimpan di dalanm monomain vesikuler, selanjutnya jika ada picuan serotonin akan terlepas menuju celah sinap. Serotonin yang terlepas akan megalami difusi menjauh dari sinap, dimetabolisme oleh monoamin oksidase, mengaktivasi reseptorpost-sinap dan mengalami re-uptake dengan bantuan transpoter serotonin pre-sinap (Ikawati, 2008).

Hasil penelitian ini sejalan dengan penelitian yang Danish National Prescription Resgister dari yang menyebutka bahwa wanita yang mengonsumsi pil kontrasepsi tanpa diagnosis depresi sebelumnya atau menggunakan antidepresan, tim peneliti menyimpulkan penggunaan segala jenis Kontrasepsi hormonal berhubungan secara positif dengan penggunaan antidepresan dan diagnosis depresi. Dr Qjvind Lidegaard, salah satu peneliti dan profesor University of Copenhagen, Denmark menjelaskan ada perbedaan kecil dalam risiko antara jenis-jenis pil itu tetapi, patch dan vaginal ring berisiko lebih tinggi dari pil kombinasi. Peneliti tersebut menemukan wanita usia 20 sampai 34 antara 1,23 dan 1,34 kali berisiko lebih tinggi (bergantung jenis kontrasepsi yang dipakai) membutuhkan antidepresan pertama kali setelah memakai kontrasepsi (Kompas, 2016). Depresi pada wanita pengguna alat kontrasepsi hormonal dapat disebabkan karena stres yang berkepanjangan. Stres dapat terjadi akibat penurunan 
kepercayaan diri akibat berat badan yang bertambah secara cepat. Hormon estrogen menyebabkan retensi air dan oedem, sedangkan progesteron mempermudah perubahan karbohidrat dan gula menjadi lemak dan merangsang nafsu makan serta menurunkan aktifitas fisik. Estrogen mempunyai efek pigmentasi yang menyebabkan bercak berwarna coklat, dan biasanya timbul di pipi dan dahi atas (Zumroatun).

\section{Simpulan dan Saran}

Simpulan penelitian menunjukkan sebagian besar akseptor menggunakan kontrasepsi hormonal. Faktor risiko penggunaan kontrasepsi hormonal menurunkan kualitas hidup fisik dan mental sosial. Akseptor yang menggunakan kontrasepsi hormonal memiliki skor kesehatan fisik dan mental yang lebih rendah dibandingkan pengguna kotrasepsi non hormonal. Perlunya memberikan konseling lengkap tentang semua metode kepada akseptor sebelum memutuskan menggunakan kontrasepsi. Pemilihan kontrasepsi hormonal oleh akseptor harus dengan pemeriksaan kesehatan lengkap, dan penggunaannya harus dengan pengawasan yang ketat, sehingga tidak meningkatakn reseko terjadinya gangguan kesehatan baik fisik maupun mental.

\section{Referensi}

Andrea, R.J., Bibiana, G.B., Karina, F. \& Ahmed, E.S. (2012). Novel effects of hormonal contraceptive use on the plasma proteome. Plos One 7(9)

BKKBN. (2017). Survey demografi dan kesehatan indonesia tahun 2017. https://www.bkkbn.go.id/ Diakses 30 Oktober 2016

BKKBN. (2015). Laporan Tahunan Metro Selatan tahun 2015. Metro: BKKBN Metro

Endah. (2012). Perbandingan Kualitas Hidup Akseptor Kontrasepsi Hormonal dan Non Hormonal. pada masyarakat di kecamatan pakem tahun 2012. Skripsi.

Eviana, S. (2011). Panduan pemeriksaan fisik. Jakarta: Salemba Medika.

George, A.A., Sheila, S., Robert, A.N., Bernice, A., Daniel, A. \& Albert, G.A. (2014). Effect of hormonal contraceptives on lipid profile and the risk indices for cardiovascular disease in a ghanaian community. International Journal of Women,s Health

Gezginc, K., Balci, O., Karatayli, R, Colakoglu MC. 2007 Contraceptiveeffi- cacyandsideeffectsofImplanon. Eur Jcontracept Reprod Health Care.

Hartanto, H. (2010). Keluarga berencana dan kontrasepsi. Jakarta: Pustaka Sinar Harapan.

Ikawati, Z. (2016). Pengantar farmakologi molekuler cetakan kedua. Yogyakarta: Gadjah Mada University Press.

Kemenkes RI. (2015). Profil Kesehatan Indonesia, 2015. Jakarta: Kemenkes RI.

Kompas. (2016). Alat Kontrasepsi Berisiko Mendatangkan Depresi Diambil dari http://lifestyle.kompas.com/ Diakses 10 Maret 2016

Michael \& Steven, O. (2014). The oxford hand book of depression and comorbidity. Oxford Library of psychology.

Natalia, Z.F. (2014). Terapi untuk gangguan depresi dengan psikotik. Referat. Jakarta: Fakultas KedokteranDepartemen Ilmu Kesehatan Jiwa dan Perilaku Universitas Katolik IndonesiaAtma Jaya.

Survei Demografi dan Kesehatan Indonesia (SDKI). (2012). Tren pemakaian kontrasepsi pada wanita kawin, Indonesia 1991-2012 [Diakses pada 24 Maret 2015]. Diambil dari http://surveidemografidankesehatanindonesiasdki.com

Varney. (2010). Manajemen kebidanan. Jakarta: EGC

Ventegody, S., Merrick, J., Andersen, N. (2003). Quality of life theory, the qol theory; an integratif theory of the global quality of life concept. Scienc World $\mathbf{J}$.

Zumroatun. (2010). Hubungan tingkat pendidikan ak- septor kb dengan pengetahuan tentang pil oral kombinasi di RB Budi Rahayu Kel. Tan- dang Kec. Tembalang Kota Semarang [internet]. Jurnal Unimus. 